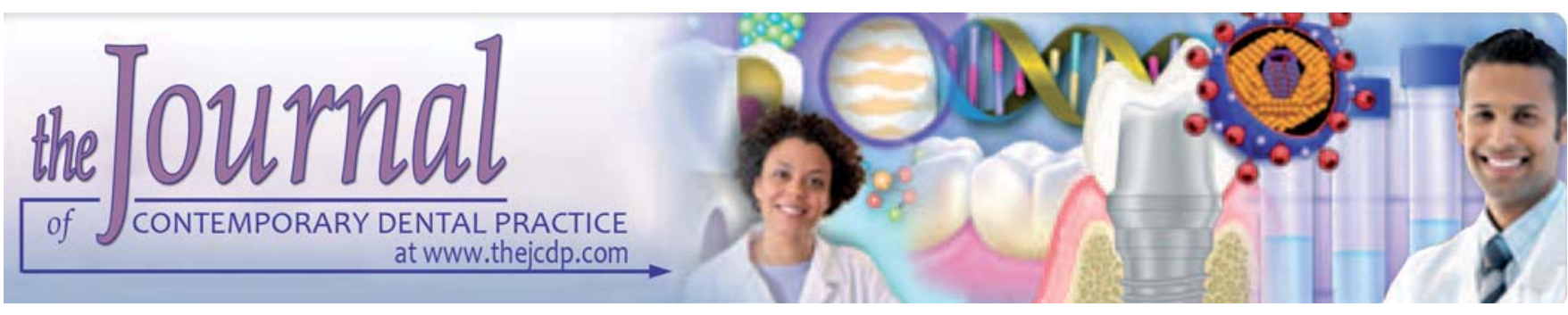

\title{
Juvenile Scleredema of Buschke
}

\author{
J Dhanuja Rani, Suneel G Patil, ST Srinivas Murthy, Ajit V Koshy, Deepak Nagpal, Sheeba Gupta
}

\section{ABSTRACT}

Aim: To recognize a line of treatment for scleredema of Buschke in an adolescent.

Background: Scleredema of Buschke is an uncommon disorder characterized by induration of the skin, which includes a non pitting hardening of the skin around the neck, shoulders, and trunk sometimes the face. Three variants are recognized. The histopathologic features of scleredema are characterized by thickened collagen bundles within the reticular dermis that are separated by mucin containing fenestrations. No consistent treatment modality is currently followed.

Case report: The present case report describes scleredema of Buschke in a 10-year-old female child reported with stiffness of facial skin and difficulty in opening the mouth. The patient was treated with antibiotics and vitamin supplements and there was drastic improvement with decrease in skin stiffness and increase in mouth opening. The stiffness of facial muscles decreased and mouth opening increased.

Conclusion: Multiple treatment modalities for scleredema have been used. In the present case, high-dose antibiotic therapy was used with good prognosis.

Clinical significance: High-dose antibiotic therapy can be used for treatment of dermatologic disorders with reasonably good prognosis.

Keywords: Scleredema of Buschke, Sjogren's syndrome, Penicillin.

How to cite this article: Rani JD, Patil SG, Murthy STS, Koshy AV, Nagpal D, Gupta S. Juvenile Scleredema of Buschke. J Contemp Dent Pract 2012;13(1):111-114.

\section{Source of support: Nil}

Conflict of interest: None declared

\section{BACKGROUND}

Scleredema of Buschke is an uncommon disorder characterized by induration of the skin that includes a nonpitting hardening of the skin around the neck, shoulders and trunk, thickening usually begins on the neck and later spreads to the shoulders, upper part of the trunk and sometimes the face. ${ }^{1,2}$
The disease was first described by Curzio in $1752,{ }^{1}$ Abraham Buschke in 1902 gave the condition the name scleredema. ${ }^{2}$ Currently, the disease is simply referred to as scleredema, or scleredema of Buschke. Three variants are recognized; the first is accompanied by an acute febrile illness like influenza, tonsillitis, pharyngitis, measles, scarlet fever, mumps, otitis, furuncles, erysipelas, impetigo, etc. In most instances, the infection is of streptococcal origin and characterized by resolution over several months, the second follows a slow progressive course with no apparent underlying disease and the third is associated with diabetes mellitus.

The histopathologic features of scleredema are characterized by thickened collagen bundles within the reticular dermis that are seperated by mucin containing fenestrations, the mucin is thought to represent nonsulfated acid mucopolysaccharides. These thickened collagen bundles are often more prominent within the deeper dermis. This process may extend into the subcutaneous fatty tissue.

Multiple treatment modalities for scleredema have been used, including bath psoralen UVA, ${ }^{3}$ cyclosporine, ${ }^{4}$ lowdose methotrexate, ${ }^{5}$ extracorporeal photopheresis ${ }^{6}$ and, in a case, high dose penicillin ${ }^{7}$ was used with good prognosis.

\section{CASE REPORT}

A 10-year-old female child reported with chief complaint of stiffness of facial skin and difficulty in opening the mouth since 1 month. On medical history, no history of any drug allergy, hospitalization or any illness, but she gave a positive history for recurrent throat infection. On extraoral examination, the skin was stiff on palpation (Fig. 1), the stiffness was seen at temple region, scalp (Fig. 2), bilaterally on the face and neck up to sternum, posteriorly up to C5, and the mouth opening was decreased. On intraoral 
examination of soft tissue, loss of stippling seen in gingiva, buccal mucosa was firm in consistency. Hematological investigation showed that the blood counts, blood sugar, blood urea, serum creatinine were within normal range and ASO titer $>200 \mathrm{IU} / \mathrm{ml}$.

Histopathological examination of a skin biopsy from the neck and buccal mucosa showed (Figs 4 to 6) swelling and splitting of dermal collagen bundles by an increase in ground substance, dermis was 3 times its normal thickness, deposition of hyaluronic acid between the collagen fibers, in dermis thick collagen bundles separated by large interfibrous spaces, fibrous noncellular hyperplasia replaces large areas of subcutaneous tissue resulting in increased skin thickness, increase in acid mucopolysaccharides.

The patient was treated with antibiotics and vitamin supplements and there was drastic improvement with

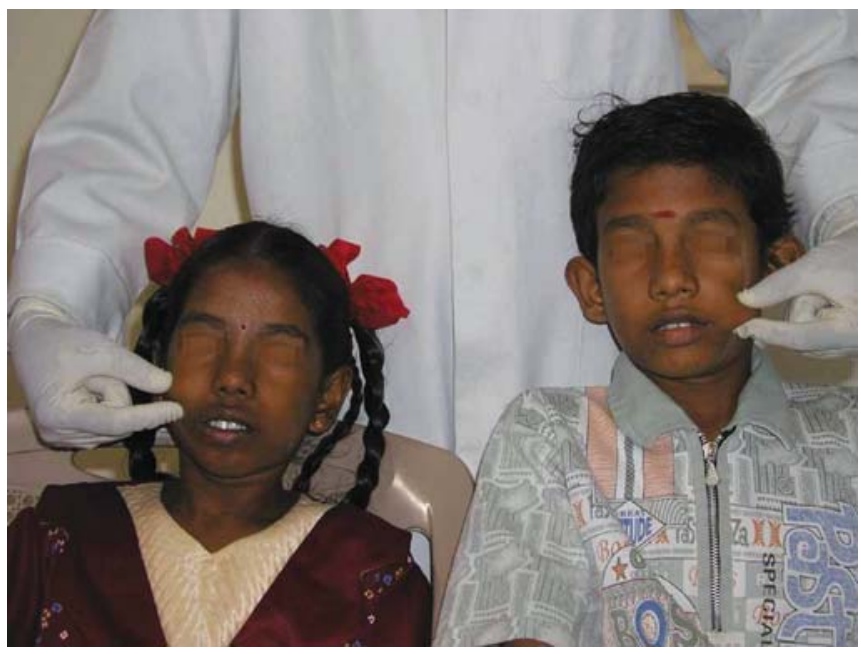

Fig. 1: Palpation of cheek

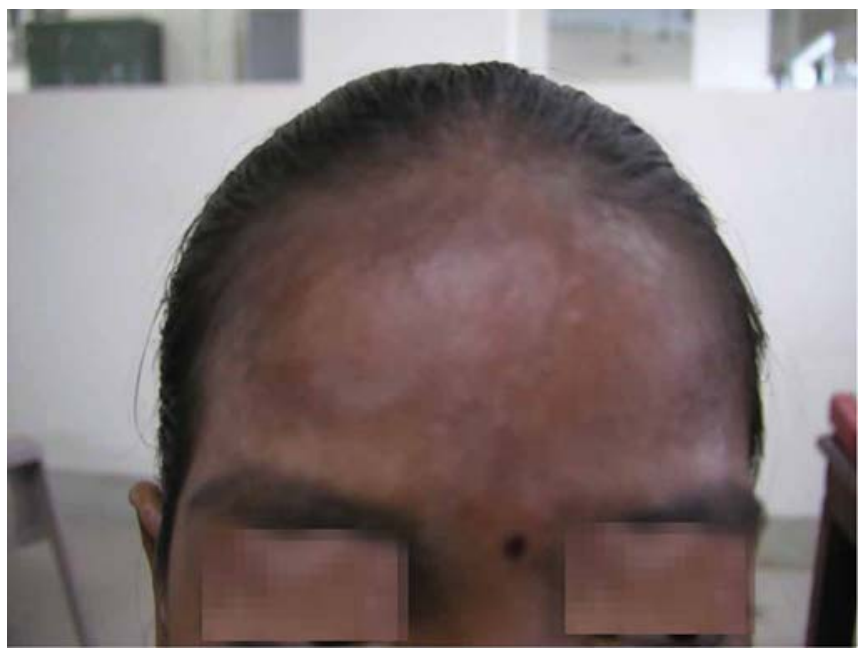

Fig. 2: Skin over scalp decrease in skin stiffness and increase in mouth opening (Table 1 and Fig. 3) in her follow-up visits.

\section{DISCUSSION}

Buschke in 1902 described this systemic disease with woody, nonpitting indurations of 'plaster statue' consistency starting at the nape of the neck and spreading throughout the body, usually symmetrically but sparing the palms and soles, ${ }^{2}$ rarely the tongue, pharynx and parotid gland may also be involved, ${ }^{8}$ there is a history of preceding infection in 65 to $90 \%$ of cases as reported in

\begin{tabular}{lccc}
\multicolumn{4}{c}{ Table 1: Measurements showing mouth opening } \\
\hline & 1st visit & $\begin{array}{c}\text { 2nd visit } \\
\text { after 1 month }\end{array}$ & $\begin{array}{c}\text { 3rd visit } \\
\text { after 2 months }\end{array}$ \\
\hline Mouth opening & $24 \mathrm{~mm}$ & $29 \mathrm{~mm}$ & $32 \mathrm{~mm}$ \\
\hline
\end{tabular}

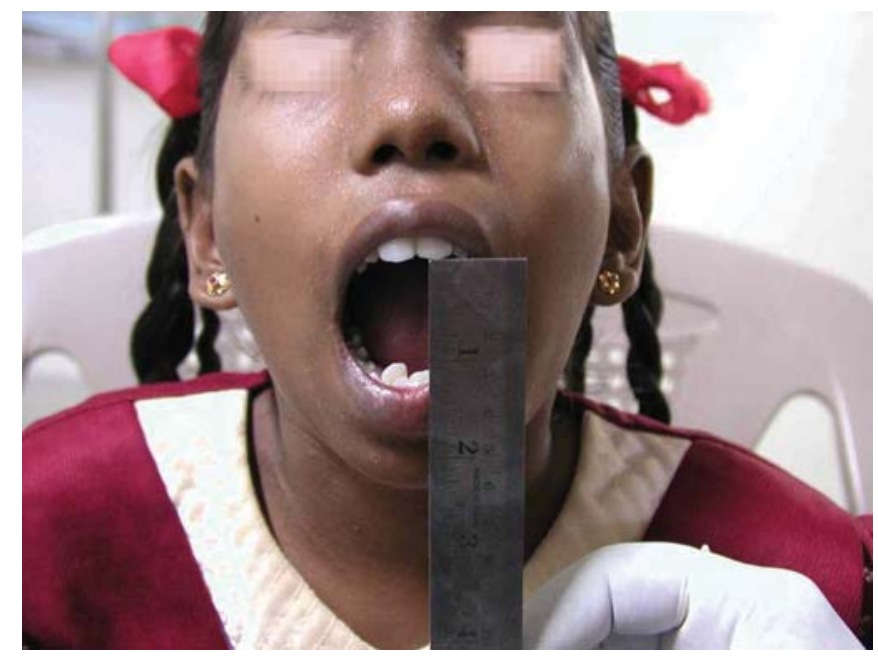

Fig. 3: Measurements showing mouth opening

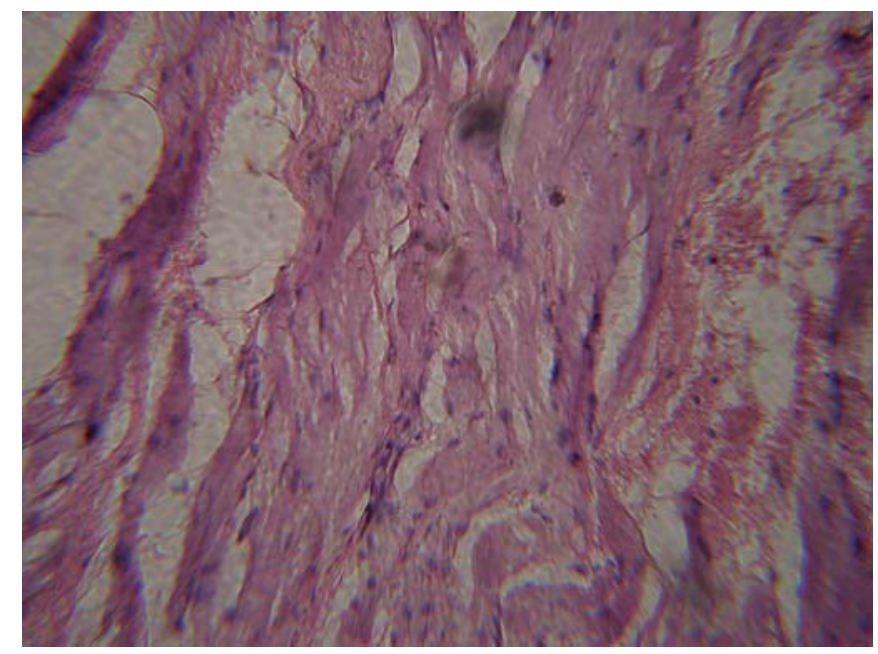

Fig. 4: (H\&E) section—edema spaces between thickened collagen fibers (HPV) 


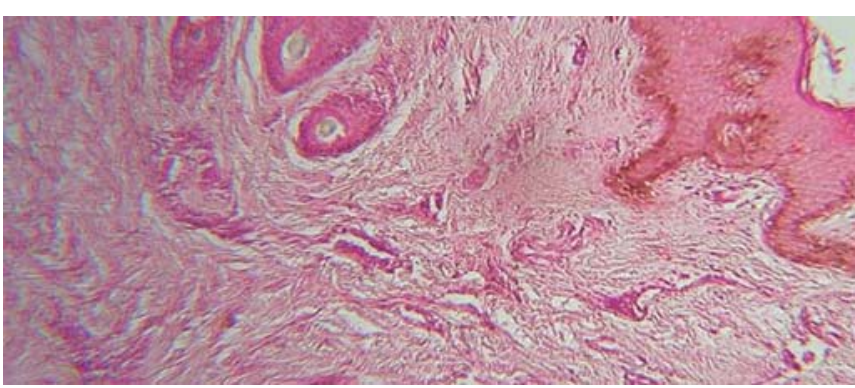

Fig. 5: (H\&E) section—edema spaces between thickened collagen fibers

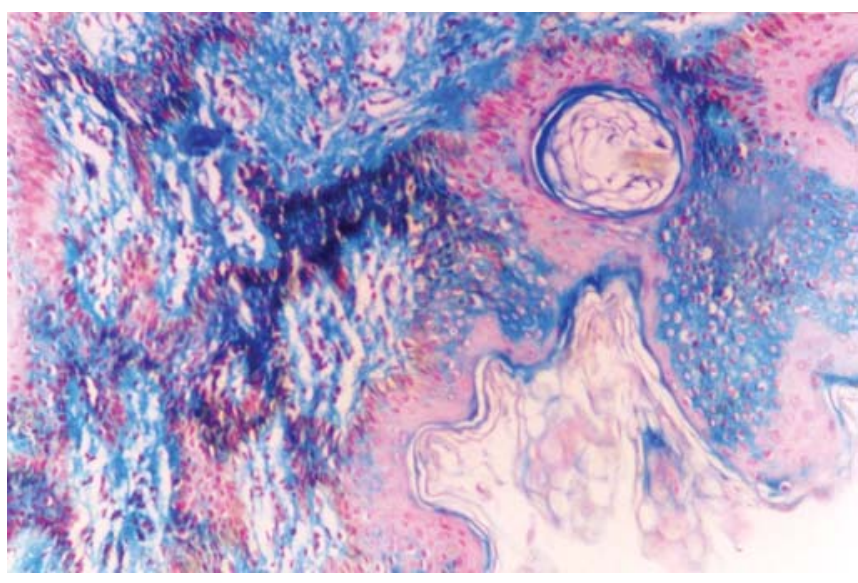

Fig. 6: Alcian blue stain demonstrating acid mucopolysacchrides

the present case, however, associations also have been reported with diabetes, ${ }^{9}$ monoclonal gammopathy, ${ }^{10}$ multiple myeloma, ${ }^{11,12}$ primary hyperparathyroidism, ${ }^{13}$ rheumatoid arthritis ${ }^{9}$ and rheumatoid arthritis with sjogren syndrome. ${ }^{14}$

The condition is usually self-limiting with active phase persisting for 2 to 8 weeks followed by spontaneous and complete resolution in 6 months to 2 years. Occasional cases with no resolution even after 10 years have been cited. The potential chronicity and severity of the disorder should not be underestimated, as there have been at least two deaths due to scleredema. ${ }^{15,16}$

Histologically, scleredema shows a normal epidermis but the dermis may be three times the normal thickness with swelling and splitting of the dermal collagen bundles and variable deposition of the mucin in the dermis, histochemical analysis have shown that the amount of glycosaminoglycans and collagenase increased in the affected skin.

\section{CONCLUSION}

There is no definitive therapy for scleredema. In the mildest cases, optimization of metabolic control and physiotherapy especially in case of motion or respiratory disability are recommended. For the rare progressing forms, various systemic treatments have been proposed including corticosteroids, D-penicillamine, cyclosporine, methotrexate, PUVA therapy, prostaglandin E1, factor XIII or radiotherapy. High-dose antibiotic therapy can prove to be a useful line of treatment of this rare disorder.

\section{CLINICAL SIGNIFICANCE}

Oral symptoms of scleredema are often neglected. Patients with this disease may have difficulty in mouth opening. High-dose antibiotic therapy and vitamins may be used for treatment of scleredema with reasonably good prognosis.

\section{REFERENCES}

1. Touraine A, Gole L, Soulignac R. Sur l'historique de "sclerodoedema del'adulte" dit de Buschke. Bull Soc Franc Dermato Syphiligro 1936;43:1842-46.

2. Buschke A. Uber scleroderma. Klin Wochenschr 1902;39: 955-57.

3. Hager CM, Sobhi HA, Hunzelmann N. Bath-PUVA therapy in three patients with scleredema adultorum. J Am Acad Dermatol 1998;38:240-42.

4. Mattheou-Vakali G, Loannides D, Thomas T, Lazaridou E, Tsogas P, Minas A. Cyclosporine in scleredema. J Am Acad Dermatol 1996;35:990-91.

5. Seyger MM, van den Hoogen FH, deMare S, vanHaelst U, deJong EM. A patient with a severe scleroedema diabeticorium, partially responding to low-dose methotrexate. Dermatology 1999;198:177-79.

6. Stables GI, Tylor PC, Highet AS. Scleredema associated with paraproteinaemia treated by extracorporeal photopheresis. Br J Dermatol 2000;142:781-83.

7. Krasagakis K, Hettmansperger U, Trautmann C, Tebbe B, Garbe C. Persistent scleredema of Buschke in a diabetic: Improvement with high-dose penicillin. $\mathrm{Br} \mathrm{J}$ Dermatol 1996;134:597-98.

8. Madison LL. Scleredema. Am J Med 1950;9:707-13.

9. Venencie PY, Powell FC, Su WP, Perry HO. Scleredema: A review of 33 cases. J Am Acad Dermatol 1984;11:128-34.

10. Venencie PY, Powell FC, Su WP, Perry HO. Scleredema and monoclonal gammopathy: Report of two cases. Acta Derm Venereol (Stockh) 1984;64:554-56.

11. Hodak E, Tamir R, David M. Scleredema adultorum associated with IgG-Kappa multiple myeloma. Clin Exp Dermatol 1988;13:271-74.

12. Salisbury JA, Shallcross H, Leigh IM. Scleredema of Buschke associated with multiple myeloma. Clin Exp Dermatol 1988;13: 269-70.

13. Berk MA. Lorincz AL. Scleredema adultorum of Buschke and primary hyperparathyroidism. Int J Dermatol 1988;27: 647-49. 
14. Miyagawa S, Dohi K, Tsuruta S, Shirai T. Scleredema of Buschke associated with rheumatoid arthritis and Sjogren's syndrome. Br J Dermatol 1989;121:517-20.

15. Leinwand I. Generalised scleredema: Report with autopsy findings. Ann Intern Med 1951;34:226-38.

16. Sansom JE, Sheehan AL, Kennedy CT, Delaney TJ. A fatal case of scleredema of Buschke. Br J Dermatol 1994;130: 394-97.

\section{ABOUT THE AUTHORS}

\section{J Dhanuja Rani}

Reader, Department of Oral and Maxillofacial Pathology, Government Dental College and Research Institute, VIMS Campus, Bellary Karnataka, India

\section{Suneel G Patil}

Assistant Professor, Department of Dentistry, Karnataka Institute of Medical Sciences, Hubli, Karnataka, India

\section{ST Srinivas Murthy (Corresponding Author)}

Reader, Department of Pedodontics and Preventive Dentistry Government Dental College and Research Institute, VIMS Campus Bellary-583104, Karnataka, India, e-mail: drsrinivaspedo@gmail.com

\section{Ajit V Koshy}

Professor and Head, Department of Oral Pathology and Microbiology MA Rangoonwala College of Dental Science and Research Centre Pune, Maharashtra, India

\section{Deepak Nagpal}

Reader, Department of Oral and Maxillofacial Pathology, Sinhgad Dental College and Hospital, Pune, Maharashtra, India

\section{Sheeba Gupta}

Reader, Department of Oral Medicine and Radiology, Swami Devi Dayal Dental College, Barwala, Haryana, India 